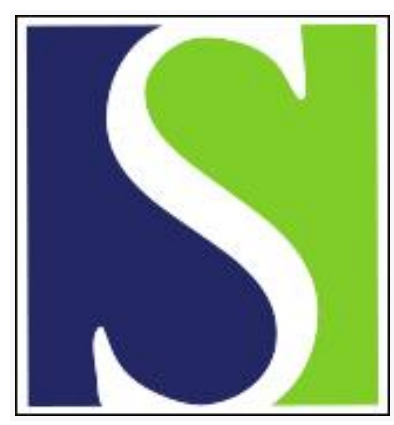

Scand J Work Environ Health 1982;8(2):94-107

https://doi.org/10.5271/sjweh.2483

Issue date: Jun 1982

Inhalation anesthetics, anticancer drugs and sterilants as chemical hazards in hospitals.

by Vainio $\mathrm{H}$

Key terms: anticancer drug; carcinogenicity; chemical hazard; ethylene oxide; formaldehyde; halothane; hexachlorophene; hospital; inhalation anesthetic; mutagenicity; nitrous oxide; reproductive hazard; spontaneous abortion; sterilant

This article in PubMed: www.ncbi.nlm.nih.gov/pubmed/7134932

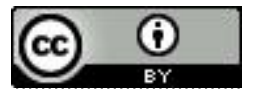




\title{
Inhalation anesthetics, anticancer drugs and sterilants as chemical hazards in hospitals
}

\author{
by Harri Vainio, $\mathrm{MD}^{1}$
}

\begin{abstract}
VAINIO $\mathrm{H}$. Inhalation anesthetics, anticancer drugs and sterilants as chemical hazards in hospitals. Scand $j$ work environ health 8 (1982) 94-107. In recent years, there has been a considerable increase in the use of chemicals (chemical sterilants and antimicrobial agents, antineoplastic drugs, and anesthetic gases) in hospitals. The possible existence of occupational health hazards has often been overlooked in light of the great advantages provided by the use of chemical agents. It appears that certain hospital sectors, such as anesthesia units, sterilizing units and oncology units, require different degrees of caution and protective measures with respect to the handling of chemicals. The scientific evidence on which recommendations should be based is, in most cases, fairly meager; until more is known about the hazards, it would be prudent to minimize the occupational exposure to chemicals in hospitals.
\end{abstract}

Key terms: carcinogenicity, ethylene oxide, formaldehyde, halothane, hexachlorophene, mutagenicity, nitrous oxide, reproductive hazards, spontaneous abortions.

Many chemical agents have been and are being used in hospitals as anesthetics, chemical sterilizers, drugs, cytostatic agents, etc. Some of these chemicals (particularly chemical sterilants and some cytostatic drugs) are highly reactive chemically. Others, such as anesthetic gases, act on lipid membranes. Until recently, little thought has been given to the possible adverse health effects of occupational exposure to chemicals in hospitals. This review examines the occupational health hazards of the types of chemicals most frequently used in hospital facilities.

\section{INHALATION ANESTHETICS}

\section{Properties and occurrence}

Inhalation anesthesia was first introduced in 1842. Since then, many different chemicals have been used as inhalation anesthetic agents. Although the possible health hazards of occupational exposure to

1 Department of Industrial Hygiene and Toxicology, Institute of Occupational Health, Helsinki, Finland.

Reprint requests to: $\mathrm{Dr} H$ Vainio, Institute of Occupational Health, Haartmaninkatu 1, SF-00290 Helsinki 29, Finland. anesthetic agents have only recently aroused interest [see the reports of Edling (22) and the National Institute for Occupational Safety and Health (65)], more attention has been paid to the physicochemical properties of such anesthetic agents.

At room temperature and room pressure inhalation anesthetics are either gases or volatile liquids. The only gas in widespread use is nitrous oxide. Other commonly used anesthetics are either halogenated ethanes or ethers. Diethyl ether, divinyl ether chloroform, trichloroethylene, and fluroxane are either flammable or considered so toxic that most countries have stopped using them.

The halogenation of aliphatic hydrocarbons decreases their volatility and flammability and, in some cases, increases their lipid solubility. Polyhalogenated compounds are also more stable than monohalogenated compounds.

The uptake and the clearance of inhalation anesthetics have recently been reviewed (29). The metabolism of these agents has been considered in another review (88).

Anesthetic agents have not only been found in the ambient air of operating rooms, but also in the ambient air of recovery rooms, delivery rooms, and dental 
surgery rooms [see Tolonen (84)]. The concentration of anesthetic waste gases and vapors depends on a variety of factors, including the method and technique of anesthesia and the specific scavanger operations done. The level of halothane frequently found in older operating rooms varies between 1 and $70 \mathrm{ppm}$, and the concentration of nitrous oxide frequently ranges from 400 to $3,000 \mathrm{ppm}$. In newer facilities with better systems of general ventilation, appreciably lower concentrations have been measured. But occasionally, some high peak exposures can occur, eg, during intubation or when a face mask is used.

Since the potential health hazards of inhalation anesthetics have been recently summarized $(22,65)$, I will not give an exhaustive literature review. However, I will discuss those adverse health hazards that are the most important from the point of view of occupational exposure.

\section{Hazards to reproduction}

The first hint that the personnel of operating rooms might be exposed to health hazards came from a Russian study by Vaisman (87). He had sent a questionnaire to 354 Russian anesthetists (of whom $28 \%$ used halothane, $59 \%$ nitrous oxide, and $98 \%$ ether) and had analyzed 303 replies. The fact that only 7 of 31 pregnancies among these doctors were trouble-free stimulated researchers in other countries to carry out similar surveys. The main concerns of these studies have been spontaneous abortions and malformed children (tables 1 \& 2).

The standard approach of each study has been to use a register to identify a group of exposed persons, who are then sent questionnaires inquiring about the past occurrence of the topics under study. These studies have provided reasonably convincing evidence of an increased risk of spontaneous abortion among exposed women (but not among the wives of exposed men).

A recent American study compared men dentists and women chairside assistants who used anesthetic gases (mainly nitrous oxide) with those who did not (15). The study showed a highly significant association between exposure to anesthetic gases and spontaneous abortions among the chairside assistants. The rate rose from 8.1 per 100 pregnancies among those not exposed to 19.1 per 100 pregnancies among those heavily exposed. Because the concentrations of anesthetic gases measured during dental surgery are several times higher than those found in general operating rooms, a survey of the pregnancies of dentists' wives could be expected to be more indicative of the effects of paternal exposure. Interestingly, an association has been observed for dentists' wives (6.7 per 100 for nonexposed husbands vs 10.2 per 100 for heavily exposed husbands). No increase in congenital malformations among the children of exposed dentists was observed.

In summary, it is reasonably conclusive that operating room staff have an increased risk of spontaneous abortion. The recent study of dentists and chairside assistants, together with evidence from experimental animals (56), suggests that high concentrations of nitrous oxide may be the causative factor.

Some studies, eg, those by Cohen et al (13), Knill-Jones et al (51), and Göthe et al (35), have reported that the children of women exposed to anesthetic gases during pregnancy have a higher risk of malformations. No increase in congenital malformations was observed among the children of dentists exposed to inhalation anesthetics (15), nor did a Swedish study of women operating room personnel find an increased occurrence of congenital malformations (25). The existing evidence for the increased risk of the birth of a malformed child is much weaker than the evidence for spontaneous abortion.

\section{Carcinogenicity and mutagenicity}

Some anesthetic agents are known to have mutagenic potential [see Baden \& Simmon (3)]. Halothane, for instance, has been found to induce recessive lethal mutations in Drosophila (53). Halothane is also able to increase the level of nondisjunction in Drosophila (11). Furthermore, halothane has reactive intermediates that can bind covalently to cellular macromolecules (30) and are mutagenic in bacterial tests (32). It has also been reported that nitrous oxide, another commonly used anesthetic 
gas, increases the number of recessive sexlinked lethal mutations in Drosophila (31).

Two retrospective epidemiologic studies have been published concerning the deaths of members of the American Society of Anesthesiologists during the intervals of 1947-1966 and 1967-1971 $(5,6)$. The study of the first period suggested that anesthetists were at an increased risk of death from tumors of the lymphatic and reticuloendothelial systems. No such difference was apparent in the later period.
A third study, done in the United Kingdom, followed over 20,000 men doctors for up to 20 a (20). Some 1,250 of the doctors were full-time or part-time anesthetists. No excess of deaths from cancer was observed, although 5 deaths from cancer of the pancreas occurred, versus 1.7 expected, among the full-time anesthetists.

In another extensive American study, morbidity was followed in a questionnaire survey of 73,496 persons. This study found a higher frequency of cancer, especially

Table 1. Surveys on spontaneous abortion among exposed females and among wives of exposed males.

\begin{tabular}{|c|c|c|c|c|c|c|c|}
\hline \multirow{3}{*}{ Subjects } & \multicolumn{3}{|c|}{ Exposed group } & \multicolumn{3}{|c|}{ Reference group } & \multirow{3}{*}{ Reference } \\
\hline & \multirow{2}{*}{$\begin{array}{l}\text { Pregnan- } \\
\text { cies } \\
\text { (N) }\end{array}$} & \multicolumn{2}{|c|}{ Abortions } & \multirow{2}{*}{$\begin{array}{l}\text { Pregnan- } \\
\text { cies } \\
\text { (N) }\end{array}$} & \multicolumn{2}{|c|}{ Abortions } & \\
\hline & & $\mathrm{N}$ & $\%$ & & $\mathrm{~N}$ & $\%$ & \\
\hline \multicolumn{8}{|l|}{ United Kingdom in 1972} \\
\hline $\begin{array}{l}\text { Doctors } \\
\text { United Kingdom in } 1975\end{array}$ & 737 & 133 & 18 & 2,150 & 323 & 15 & Knill-Jones et al (51) \\
\hline $\begin{array}{l}\text { Doctors } \\
\text { United States in } 1971\end{array}$ & 523 & 84 & 16 & 7,296 & 803 & 11 & Knill-Jones et al (50) \\
\hline $\begin{array}{l}\text { Nurses } \\
\text { Doctors }\end{array}$ & $\begin{array}{l}36 \\
37\end{array}$ & $\begin{array}{l}11 \\
14\end{array}$ & $\begin{array}{l}28 \\
38\end{array}$ & $\begin{array}{l}34 \\
58\end{array}$ & $\begin{array}{l}3 \\
6\end{array}$ & $\begin{array}{r}9 \\
10\end{array}$ & $\begin{array}{l}\text { Cohen et al (12) } \\
\text { Cohen et al (12) }\end{array}$ \\
\hline \multicolumn{8}{|l|}{ United States in 1974} \\
\hline $\begin{array}{l}\text { Nurses } \\
\text { Doctors }\end{array}$ & $\begin{array}{r}1,826 \\
468\end{array}$ & $\begin{array}{r}310 \\
80\end{array}$ & $\begin{array}{l}17 \\
17\end{array}$ & $\begin{array}{r}1,948 \\
308\end{array}$ & $\begin{array}{r}292 \\
28\end{array}$ & $\begin{array}{r}15 \\
9\end{array}$ & $\begin{array}{l}\text { Cohen et al (13) } \\
\text { Corbett et al (17) }\end{array}$ \\
\hline $\begin{array}{l}\text { Finland in } 1973 \\
\text { Nurses }\end{array}$ & 257 & 51 & 20 & 150 & 17 & 11 & Rosenberg \& Kirves (77) \\
\hline $\begin{array}{l}\text { United Kingdom in } 1975 \\
\text { Wives of exposed doctors } \\
\text { United States in } 1974\end{array}$ & 5,891 & 648 & 11 & 7,296 & 803 & 11 & Knill-Jones et al $(50)$ \\
\hline $\begin{array}{l}\text { Wives of exposed nurses } \\
\text { Wives of exposed doctors }\end{array}$ & $\begin{array}{l}1,350 \\
3,416\end{array}$ & $\begin{array}{l}162 \\
410\end{array}$ & $\begin{array}{l}12 \\
12\end{array}$ & $\begin{array}{r}54 \\
1,982\end{array}$ & $\begin{array}{r}5 \\
258\end{array}$ & $\begin{array}{l}10 \\
13\end{array}$ & $\begin{array}{l}\text { Cohen et al (13) } \\
\text { Corbett et al (17) }\end{array}$ \\
\hline
\end{tabular}

Table 2. Major malformations in children of exposed females and wives of exposed males.

\begin{tabular}{|c|c|c|c|c|c|c|c|}
\hline \multirow{3}{*}{ Subjects } & \multicolumn{3}{|c|}{ Exposed group } & \multicolumn{3}{|c|}{ Reference group } & \multirow{3}{*}{ Reference } \\
\hline & \multirow{2}{*}{$\begin{array}{l}\text { Infants } \\
\text { born } \\
(\mathrm{N})\end{array}$} & \multicolumn{2}{|c|}{$\begin{array}{c}\text { Infants } \\
\text { malformed }\end{array}$} & \multirow{2}{*}{$\begin{array}{l}\text { Infants } \\
\text { (N) }\end{array}$} & \multicolumn{2}{|c|}{$\begin{array}{l}\text { Infants } \\
\text { malformed }\end{array}$} & \\
\hline & & $\bar{N}$ & $\%$ & & $\mathrm{~N}$ & $\%$ & \\
\hline \multicolumn{8}{|l|}{ United Kingdom in 1972} \\
\hline $\begin{array}{l}\text { Doctors } \\
\text { United Kingdom in } 1975\end{array}$ & 893 & 27 & 3 & 1,835 & 59 & 3.2 & Knill-Jones et al (51) \\
\hline $\begin{array}{l}\text { Doctors } \\
\text { United States in } 1974\end{array}$ & 438 & 7 & 1.6 & 6,442 & 71 & 1.1 & Knill-Jones et al $(50)$ \\
\hline $\begin{array}{l}\text { Nurses } \\
\text { Doctors }\end{array}$ & $\begin{array}{r}1,480 \\
384\end{array}$ & $\begin{array}{r}142 \\
23\end{array}$ & $\begin{array}{l}9.6 \\
5.9\end{array}$ & $\begin{array}{r}1,629 \\
276\end{array}$ & $\begin{array}{r}124 \\
8\end{array}$ & $\begin{array}{l}7.6 \\
3.0\end{array}$ & $\begin{array}{l}\text { Cohen et al (13) } \\
\text { Corbett et al (17) }\end{array}$ \\
\hline \multicolumn{8}{|l|}{ Finland in 1973} \\
\hline Nurses & 207 & 0 & 0 & 133 & 0 & 0 & Rosenberg \& Kirves (77) \\
\hline $\begin{array}{l}\text { United Kingdom in } 1975 \\
\text { Wives of doctors } \\
\text { United States in } 1974\end{array}$ & 5,175 & 57 & 1.1 & 6,442 & 71 & 1.1 & Knill-Jones et al (50) \\
\hline $\begin{array}{l}\text { Wives of nurses } \\
\text { Wives of doctors }\end{array}$ & $\begin{array}{l}1,168 \\
2,988\end{array}$ & $\begin{array}{r}96 \\
161\end{array}$ & $\begin{array}{l}8.2 \\
5.4\end{array}$ & $\begin{array}{r}49 \\
1,714\end{array}$ & $\begin{array}{r}2 \\
72\end{array}$ & $\begin{array}{l}3.7 \\
4.2\end{array}$ & $\begin{array}{l}\text { Cohen et al (13) } \\
\text { Corbett et al (17) }\end{array}$ \\
\hline
\end{tabular}


leukemia and lymphoma (13), among the women exposed to anesthetic gases. No such higher frequency was found for the men with such exposure.

In conclusion, the evidence that inhalation anesthetic gases cause increased cancer risk among exposed persons is still fairly limited. Some of the anesthetic agents are, however, known to be active mutagenically in various test systems. Therefore, special attention should be paid to the epidemiologic surveillance of persons exposed to anesthetic agents.

\section{Liver disease}

Uncertainty about whether halothane causes hepatitis has led to much debate. Although halothane itself is not directly toxic to the liver, its metabolites fulfill the criteria for hepatotoxins (30). In many animal experiments hepatocellular damage has been reported after exposure to high doses of halothane and methoxyflurane (65), and also after long-term exposure to low doses of halothane, isoflurane, and diethyl ether (83). However, the only available data for man are the case reports of liver damage either among patients anesthesized with halothane or among anesthetists exposed to halothane [see, Edling (22)]. A few comprehensive epidemiologic studies have reported an increased frequency of liver disease among anesthesiologists $(13,14,65,82)$.

\section{Renal damage}

Methoxyflurane is known to cause renal tubular necrosis in experimental animals and man $(16,61,65)$. The actual cause of renal damage may be the metabolites inorganic fluoride and oxalic acid. Increased fluoride concentrations in the urine of delivery ward and operating room personnel have been measured (18). One survey, done by Bruce et al (5), suggested an increased incidence of chronic renal disease as a cause of death among anesthetists.

At concentrations of 10 to $500 \mathrm{ppm}$ halothane has caused morphologically detectable kidney damage in rats (9). Several volatile metabolites of halothane are nephrotoxic in mice (79).

\section{Toxic effects in the central nervous system}

Anesthetic agents are lipid-soluble narcotizing gases or solvents. Thus they also have the potential to cause chronic toxic effects in the central nervous system. Some of the recent evidence for the neurotoxicity of anesthetic agents has been given in a review by Edling (22). The central issue is an almost complete lack of studies on the chronic neurotoxic effects produced after many years of exposure to anesthetic gases.

The results of studies of the acute effects on the central nervous system are somewhat contradictory. Korttila et al (52) found no impairment in the driving skills of nurses after occupational exposure to halothane $(0-43.7 \mathrm{ppm})$ and nitrous oxide $(100-1,200 \mathrm{ppm})$. A Swedish study of 32 anesthetic nurses found a tendency towards poorer performance on psychological tests in a high exposure group (41). Cohen et al (15) reported that dentists and chairside assistants exposed to nitrous oxide had a 1.8-fold to 4.4-fold increase in nonspecific neurological symptoms (tingling, numbness, and muscle weakness) when compared with colleagues without long-term exposure to subanesthetic levels of nitrous oxide. In experimental animals, halothane has been shown to cause damage to the central nervous system at concentrations as low as 8-12 ppm $(8,76)$. Layzer (57) collected data about 15 cases of nitrous oxide neurotoxicity in the United States. Twelve of these involved dentists who had repeatedly administered nitrous oxide to themselves and who had also been exposed to the gas during their occupational activities. Neurological examinations revealed sensorimotor neuropathy and a picture similar to that of subacute, combined degeneration of the spinal cord (58).

\section{Other health hazards}

Anesthetic gases have repeatedly been shown to depress the immune response [for a review, see Graham (36)]. Both nonspecific and specific immune responses can be affected. However, at present, scientists do not sufficiently understand the impact of these effects on health.

Various studies suggest that long-term exposure to nitrous oxide can cause both 
impaired metabolism of vitamin $B_{12}$ and the production of tetrahydrofolate (2). These findings may explain a syndrome (which involves early sensory complaints, loss of balance, leg weakness, gait ataxia, impotence, and sphincter disturbances) that develops in individuals exposed to nitrous oxide for long periods of time (57).

\section{Summary and recommendations}

Evaluating the risks associated with longterm exposure to low doses of anesthetics is a difficult matter of immediate concern. At present, it can be stated with reasonable conclusiveness that operating room personnel have an increased risk of spontaneous abortion. Furthermore, there is reason to believe that nitrous oxide is the causative factor. This does not mean that other anesthetic agents, eg, halothane, should be regarded without suspicion.

Intermittent exposure to high concentrations of nitrous oxide can apparently induce lesions indicating interference with the metabolism of vitamin $\mathrm{B}_{12}$. The other effects are more controversial. The increased risk of exposed women having malformed children, the increased risk of spontaneous abortion among women whose husbands have been exposed to anesthetic gases, and the chronic effects on the central nervous system, the liver, and the kidneys all need further evidence and support before they can be considered conclusive.

In view of the suggestive evidence of problems associated with long-term exposure to anesthetics, a prudent health policy would be to strive to use the technology currently available for the reduction of occupational exposure to all anesthetic agents.

\section{ANTICANCER CHEMOTHERAPEUTIC DRUGS}

\section{Properties and occurrence}

Cancer chemotherapy, a relatively new means of treating cancer, came into use around the end of the 1940s, when nitrogen mustard and its derivatives were introduced. The carcinogenicity of $\mathrm{HN}_{2}$ has been recognized since 1949 , the carcinogenicity of triethylenemelamine since 1954, and that of cyclophosphamide since 1966 [see the report of Schmäl (78)]. The possible genotoxic health effects of these drugs and their carcinogenicity, mutagenicity, and teratogenicity have since received increasing attention. During recent years the number of reports on the formation of secondary tumors after cytostatic treatment has increased $(1,39,71,80)$.

\section{Mutagenicity, carcinogenicity and teratogenicity}

Rodent carcinogenesis bioassays have provided ample evidence that the alkylating agents, as a class, are potent carcinogens in animals (table 3). In mice and rats, nitrogen mustard, triethylenemelamine, chlorambucil, melphalan, and cyclophosphamide have induced pulmonary tumors and, in some instances, other tumors such as sarcomas, lymphomas, and leukemia. Some antimetabolites are also carcinogenic in animals, although it is not clear whether this carcinogenicity represents a direct oncogenic effect. Thus many of the alkylating agents, many of the antitumor antibiotics, and some of the antitumor antimetabolites are carcinogens in animals. Two synthetic antitumor agents (methylnitrosourea and procarbazine) are also strongly carcinogenic. The case reports and clinical surveys describing the emergence of a second tumor after chemotherapy for an original tumor provide some evidence, albeit circumstantial, that these agents may have similarly carcinogenic effects on man.

Alkylating agents are very reactive towards molecules with negative charges (nucleophiles) such as ionized carboxylic and phosphoric acids and thiols. Alkylating agents are also highly reactive towards molecules with negative areas due to the presence of amine groups. These agents react with many biological constituents, including nucleic acids and proteins.

Amino acid antagonists inhibit the synthesis of protein. A few amino acid antagonists (eg, mercaptopurine, methotrexate, and aminopterin) are both teratogenic and mutagenic. Spindle poisons which are both teratogenic and mutagenic include vinblastine and vincristine. 


\section{Anticancer drugs and the liver}

The liver plays a prominent role in the metabolic activation and degradation of many antineoplastic agents (table 4). Thus the occurrence of clinical liver disturbances among patients treated with antineoplastic drugs has become an important problem. Simultaneously, increasing emphasis is being placed on the possible hepatic effects of long-term, low-grade occupational exposure among hospital personnel. Ménard et al (63) have recently published a review of the effects of antineoplastic agents on the liver.
Most clinical reports published on the hepatotoxicity of antineoplastic drugs do not even consider all other possible causes of liver toxicity. Therefore the assessment of the hepatotoxicity is necessarily somewhat arbitrary.

Once antineoplastic drugs have shown hepatotoxicity in patients, the medical surveillance of the personnel of anticancer units should be intensified.

\section{Occupational health hazards}

The handling of cytostatic drugs by hospital personnel may constitute an occupa-

Table 3. Summary of commonly used anticancer agents with carcinogenic, mutagenic, teratogenic, or immunosuppressive effects. ${ }^{a}[M=$ mouse, $\mathrm{R}=$ rat, $\mathrm{Mk}=$ monkey, $\mathrm{Rb}=$ rabbit, $\mathrm{H}=$ hamster, $\mathrm{BCNU}=1,3-\mathrm{bis}(2$ chloroethyl)-1-nitrosourea].

\begin{tabular}{|c|c|c|c|c|c|}
\hline \multirow{2}{*}{ Drug class } & \multirow{2}{*}{$\begin{array}{l}\text { Carcino- } \\
\text { genicity }\end{array}$} & \multicolumn{2}{|c|}{ Mutagenicity } & \multirow{2}{*}{$\begin{array}{l}\text { Terato- } \\
\text { genicity }\end{array}$} & \multirow{2}{*}{$\begin{array}{l}\text { Immuno- } \\
\text { suppressive } \\
\text { activity }\end{array}$} \\
\hline & & Animal & Ames & & \\
\hline \multicolumn{6}{|l|}{ Alkylating agents } \\
\hline $\begin{array}{l}\text { BCNU } \\
\text { Busulfan } \\
\text { Chlorambucil } \\
\text { Cyclophosphamide } \\
\text { Dibromomannitol } \\
\text { Nitrogen mustard } \\
\text { Phenylalanine mustard } \\
\text { Thiotepa } \\
\text { Triethylenemelamine } \\
\text { Cis-diamminedichloro- } \\
\text { platinum (II) }\end{array}$ & $\begin{array}{c}M \\
M \\
M, R \\
M, R \\
M, R \\
M \\
M, R \\
M \\
M, R\end{array}$ & $\begin{array}{l}\mathrm{R} \\
\mathrm{M} \\
\mathrm{M} \\
\mathrm{M} \\
\mathrm{M} \\
\mathrm{M}\end{array}$ & $\begin{array}{l}+ \\
+ \\
+ \\
+\end{array}$ & $\begin{array}{c}\text { R } \\
\text { R } \\
M, R \\
M, R, R b \\
M, R \\
M, R \\
M, R\end{array}$ & $\begin{array}{l}+ \\
+ \\
+ \\
+ \\
+ \\
+\end{array}$ \\
\hline \multicolumn{6}{|l|}{ Antibiotics } \\
\hline $\begin{array}{l}\text { Actinomycin D } \\
\text { Adrianmycin } \\
\text { Asparaginase } \\
\text { Bleomycin } \\
\text { Daunomycin } \\
\text { Mithramycin } \\
\text { Mitomycin C } \\
\text { Streptozotocin }\end{array}$ & $\begin{array}{c}\mathrm{R} \\
\mathrm{M}, \mathrm{R} \\
\mathrm{M}, \mathrm{R}\end{array}$ & $M$ & $\begin{array}{l}\overline{+} \\
+\end{array}$ & $\begin{array}{c}\mathrm{R}, \mathrm{Rb} \\
\mathrm{R} \\
\mathrm{R} \\
\mathrm{R}\end{array}$ & $\begin{array}{l}+ \\
+ \\
+ \\
+ \\
+\end{array}$ \\
\hline \multicolumn{6}{|l|}{ Antimetabolites } \\
\hline $\begin{array}{l}\text { Cytosine arabinoside } \\
\text { 5-Fluorouracil } \\
\text { 6-Mercaptopurine } \\
\text { Methotrexate } \\
\text { 6-Thioguanine }\end{array}$ & $\begin{array}{l}\text { M, R } \\
\text { M, H }\end{array}$ & M & + & $\begin{array}{c}\mathrm{R} \\
\mathrm{M}, \mathrm{R}, \mathrm{Mk} \\
\mathrm{R} \\
\mathrm{R}, \mathrm{Mk}\end{array}$ & $\begin{array}{l}+ \\
+ \\
+ \\
+ \\
+\end{array}$ \\
\hline \multicolumn{6}{|l|}{ Mitotic inhibitors } \\
\hline $\begin{array}{l}\text { Vincristine } \\
\text { Vinblastine }\end{array}$ & & M & & $\begin{array}{l}M, R, H, M k \\
M, R, H, M k\end{array}$ & $\begin{array}{l}+ \\
+\end{array}$ \\
\hline \multicolumn{6}{|l|}{ Miscellaneous } \\
\hline $\begin{array}{l}\text { Hydroxyurea } \\
\text { DTIC } \\
\text { Procarbazine }\end{array}$ & $\begin{array}{c}M \\
M, R \\
M, R, M k\end{array}$ & M & & $\begin{array}{c}R, H, M k \\
M, R, R b \\
\text { R }\end{array}$ & $\begin{array}{l}+ \\
+\end{array}$ \\
\hline
\end{tabular}

a Data summarized from Sieber \& Adamson (80), Weisburger et al (91), Harris (40), Adamson \& Sieber (1), and Guarino (37). 
tional health hazard. One way of assessing the individual's possible exposure to mutagenic or carcinogenic agents is to analyze chromosome damage and sister chromatid exchanges (SCEs) in peripheral blood lymphocytes.

All the drugs which bind to deoxyribonucleic acid (DNA) or give rise to structural DNA damage seem to increase the frequency of SCEs, whereas cytostatic agents interfering with the precursor supply of DNA synthesis have no such effect. A few exceptions to this rule, however, do exist. For instance, actinomycin $\mathrm{D}$ and bleomycin either bind to DNA or cause chromosome aberrations in vitro, but they have not been shown to induce SCEs in vivo (55).

Results from several in vitro studies with human lymphocytes suggest that mono- and bifunctional alkylating agents such as mitomycin $\mathrm{C}$, chlorambucil, thiotepa (59), and busulphan (48) cause a marked increase in the frequency of SCEs, but two antimetabolites (methotrexate and cytarabine) and one antitumor antibiotic (bleomycin) have no such effect (59).

Two studies have been performed on hospital personnel who handle cytostatic drugs. In a Finnish study, Norppa et al (70) found an increased frequency of SCEs in the blood lymphocytes of nurses handling cytostatic drugs. The nurses were compared with a group of office workers. The nurses in oncology wards also had a higher frequency of SCEs than other hospital nurses, but this difference was not statistically significant. The frequency of SCEs among patients receiving cytostatic drugs was highly increased. Waksvik et al (89) showed that a group of 11 nurses handling cytostatics in a cancer clinic had a small but significantly increased frequency of SCEs in their peripheral blood lymphocytes when compared with a group of ten female hospital clerks.

The urine of nurses with an increased frequency of SCEs in their lymphocytes also had increased mutagenic activity when compared with office personnel (28).

Table 4. Classification of the antineoplastic agents according to their hepatic disposition and their hepatotoxicity in man (63).

\begin{tabular}{|c|c|c|c|}
\hline Drug class & Hepatic metabolism & Biliary excretion & Hepatotoxicity \\
\hline \multicolumn{4}{|l|}{ Alkylating agents a } \\
\hline BCNU & + & + & + \\
\hline CCNU & + & + & - \\
\hline Methyl-CCNU & + & + & $?$ \\
\hline Busulfan & + & $?$ & - \\
\hline Chlorozotocin & $?$ & $?$ & $?$ \\
\hline Streptozotocin & ? & $?$ & + \\
\hline DTIC & + & - & 一 \\
\hline Cyclophosphamide & + & $?$ & - \\
\hline \multicolumn{4}{|l|}{ Antibiotics } \\
\hline Adriamycin & + & $f$ & - \\
\hline Asparaginase & $?$ & $?$ & + \\
\hline Bleomycin & + & - & $?$ \\
\hline Daunomycin & + & + & - \\
\hline Mithramycin & $?$ & $?$ & + \\
\hline Mitomycin C & + & + & $?$ \\
\hline Rubidazone & + & + & - \\
\hline \multicolumn{4}{|l|}{ Antimetabolites } \\
\hline Azathioprine & + & - & + \\
\hline Methotrexate & + & + & + \\
\hline 6-Mercaptopurine & + & - & + \\
\hline \multicolumn{4}{|l|}{ Mitotic inhibitors } \\
\hline Vincristine & + & + & - \\
\hline Vinblastine & + & + & - \\
\hline
\end{tabular}

a $\quad \mathrm{BCNU}=1,3$-bis(2-chloroethyl)-1-nitrosourea, $\mathrm{CCNU}=1$-[2-chloroethyl-3-(4-methylcyclohexyl)]-1-nitrosurea, DTIC = 5-(3,3-dimethyl-1-triazeno)-imidazole-4-carboxamide. 
Not only SCEs, but also chromosome gaps, have been reported to be more frequent in nurses handling cytostatic drugs than in hospital clerks (89). The chromatid gap in itself may not represent serious chromosome damage, but an increase in the frequency of such gaps indicates exposure to mutagenic agents (7).

All of these findings suggest that handling cytostatic drugs constitutes a possible health hazard. Therefore protective measures should be taken when cytostatic drugs are handled.

\section{Summary and recommendations}

Although the clinical toxicity of antineoplastic drugs has been well documented, there is little information about the problems that may arise immediately after such agents are handled. Many of these drugs directly irritate the skin, the eyes, the mucous membranes, and other tissues. If handled without due care, most anticancer drugs can cause toxic or allergic local reactions or both. In addition the risks of carcinogenicity and mutagenicity should always be kept in mind by the personnel who administer these drugs. A sensitive monitoring procedure showed that the concentrated urine of nurses who handle cytostatic drugs had mutagenic activity (28). Two studies reported slightly increased frequencies of SCEs in the lymphocytes of nurses handling cytostatic drugs $(70,89)$. In light of the present evidence, precautions should be taken when anticancer drugs are handled in hospitals. In general, the staff members of oncology units should avoid direct contact with these drugs by wearing protective gloves and face masks. Fume cabinets should be used when capsules and suspensions are being prepared.

\section{CHEMICAL STERILANTS}

Sterilization aims at the total destruction of all forms of microbial life. A number of chemicals have been used for this purpose (eg, ethylene oxide, formaldehyde, propylene oxide, glutaraldehyde, methyl bromide, $\beta$-propiolactone, etc). Furthermore, a number of antimicrobial agents that inhibit the growth of bacteria is used in hospitals. One agent that has caused much concern is hexachlorophene.

\section{Ethylene oxide}

\section{Properties and occurrence}

At room temperature and atmospheric pressure, ethylene oxide is a colorless gas. The mean concentration at which odor can be detected is about $700 \mathrm{ppm}\left(1,260 \mathrm{mg} / \mathrm{m}^{3}\right)$ (10). Ethylene oxide is highly reactive and potentially explosive when heated. So that the risk of explosion can be reduced, ethylene oxide is often mixed with other substances, eg, $12 \%$ ethylene oxide and $88 \%$ halocarbon. Ethylene oxide, a high volume chemical, is used primarily in chemical plants, where it is first produced and then used for intermediates. But ethylene oxide is also used as a chemical sterilant in hospitals (66). Reviews of the health hazards of ethylene oxide have recently been published $(24,67)$.

\section{Mutagenicity, carcinogenicity and teratogenicity}

Ethylene oxide is known to be mutagenic in a number of test systems $(24,66,67)$, and it binds covalently to DNA. For this reason the US National Institute for Occupational Safety and Health has concluded that occupational exposure to ethylene oxide may increase the frequency of mutations in an exposed human population (66).

Only recently, a long-term inhalation study of rats was completed. The animals were exposed to ethylene oxide in concentrations of 10,33 and $100 \mathrm{ppm}$ for $6 \mathrm{~h} / \mathrm{d}$, $5 \mathrm{~d} /$ week, for about $2 \mathrm{a}$. At the end of the experiment, the incidence of mononuclear cell leukemia in female rats was doserelated, and it increased linearly with increasing concentrations of exposure. Male rats also had a higher frequency of mononuclear cell leukemia, an earlier outcome, or both. Peritoneal mesothelioma was reported to be treatment-related in male rats exposed to 33 and $100 \mathrm{ppm}$ (81).

By subcutaneously injecting ethylene oxide (weekly dosages of $0.1,0.3$, or $1.0 \mathrm{mg} /$ animal), Dunkelberg (21) obtained sarcomas at the injection site. Sarcomas were not found in the controls. 
In 1979 Hogstedt et al (46) reported the results of a retrospective mortality study of workers employed at a Swedish ethylene oxide plant. Nine deaths from cancer were found, whereas 3.4 were expected. With regard to cause-specific mortality, two leukemia deaths were found, versus 0.14 expected. The levels of exposure were estimated to have been $10-50 \mathrm{mg} / \mathrm{m}^{3}$ (6$28 \mathrm{ppm}$ ) in the 1950s and 1960s.

In another survey Hogstedt et al (47) reported an investigation of leukemia among workers possibly exposed to ethylene oxide at a Swedish factory where a mixture of $50 \%$ ethylene oxide and $50 \%$ methyl formate had been used since 1968 to sterilize hospital equipment. Between 1972 and 1977, three persons (two women and one man) from a workforce of 230 persons had contracted leukemia ( 0.2 expected). The 8-h time-weighted average concentration of ethylene oxide in the breathing zone was estimated to have been 20 (SD 10) ppm.

The teratogenic potential of ethylene oxide has been tested in mice (54). The results indicate that ethylene oxide is a teratogen in mice when administered intravenously in a dose of $150 \mathrm{mg} / \mathrm{kg}$ each day on days $6-8$ of gestation.

\section{Occupational exposure in hospitals}

Garry et al (33) studied people working in a hospital sterilization facility. The measured ambient concentration of ethylene oxide in the sterilizer room was $36 \mathrm{ppm}$. Four exposed persons who reported upper respiratory and neurological symptoms also had significantly increased frequencies of SCES in their lymphocytes. Similar increases in SCEs have been found by other authors $(55,67)$. Chromosome aberrations have also been found in persons accidently exposed to high concentrations of ethylene oxide (23).

A recent Swedish study found cytogenetic damage in workers exposed to fairly low concentrations of ethylene oxide (45). Fifteen of 28 exposed persons had never been exposed to ethylene oxide levels exceeding $1 \mathrm{ppm}$ as an 8-h time-weighted average. The other 13 persons had been exposed to somewhat higher levels for up to 2.5 a before the investigation, but however their exposure had never exceeded
$5 \mathrm{ppm}$. The effect of ethylene oxide on the frequency of micronuclei in peripheral lymphocytes was even more pronounced than that of smoking.

\section{Summary and recommendations}

Ethylene oxide has caused significant increases in mononuclear cell leukemia in rats. The mutagenicity of ethylene oxide has been demonstrated convincingly. Epidemiologic findings suggest an association between ethylene oxide and leukemia. The causal inference from animal studies is compatible with the excesses of cancer found among workers exposed to ethylene oxide.

On the basis of the presented findings, prudent health policy would require that exposure to ethylene oxide be kept at the lowest possible level.

\section{Formaldehyde}

\section{Properties and occurrence}

Formaldehyde is a highly reactive, colorless, flammable gas. In hospitals, formaldehyde is used both as a chemical sterilant and as an aqueous solution in pathology laboratories. In some countries, formaldehyde is used in embalming fluids. Outside the hospital environment, formaldehyde has widespread use in the paper industry, in the particle-board and plywood industry, etc (68).

The toxicity of formaldehyde has been reviewed recently $(25,26,68)$.

\section{Mutagenicity, carcinogenicity and teratogenicity}

Formaldehyde is mutagenic to bacteria yeast and to the fruit fly (27). It induces SCEs in Chinese hamster ovary cells and in cultures of peripheral human lymphocytes. Chromosome aberrations have been found in mammalian cells, in plants, and in the spermatocytes of both grasshoppers and fruit flies which have been tested with formaldehyde.

Animal carcinogenicity studies. The Chemical Industry Institute of Toxicology sponsored a study, conducted by Battelle 
Columbus Laboratories, which was the first to show evidence for the carcinogenicity of formaldehyde. After 24 months of exposure to $15 \mathrm{ppm}$ of formaldehyde, 93 of 240 rats developed squamous cell carcinomas of the nasal turbinates. Two rats exposed to $6 \mathrm{ppm}$ and two mice exposed to $15 \mathrm{ppm}$ of formaldehyde also developed squamous cell carcinomas of the nasal turbinates (67).

Studies done at the New York University Medical Center confirm the findings of the Chemical Industry Institute of Toxicology. In these studies, hydrochloric acid, also a potent irritant, was used as the exposing agent. Hydrochloric acid alone did not produce cancer (86).

Epidemiologic studies. Three cases of cancer in the nasal cavities, the sinuses, or the nasopharynx were reported among Danish doctors during the period 19431976 (49). None of them had worked in a pathology department.

In the United States excess primary liver cancer and lung cancer have been reported among pathologists when compared with radiologists $(60)$. There is no way of connecting these cancers causally to formaldehyde exposure.

In summary, the existing epidemiologic studies are inadequate to provide any evidence for the possible carcinogenicity of formaldehyde in humans.

\section{Other health effects}

The acute effects of formaldehyde in man have been well documented (69). Irritation of the eyes, the nose, and the throat is associated with exposure to formaldehyde. Such irritation can lead to lacrimation, sneezing, shortness of breath, sleeplessness, a tight chest, nausea, and excess phlegm. Most people experience irritation of the eyes, the nose, and the throat when $0.1-3 \mathrm{ppm}$ of formaldehyde is present in the air.

Five nurses working near an artificial kidney (hemodialysis) machine developed wheezing and recurrent episodes of cough (42). The formaldehyde used to sterilize the machine was reported to have caused this respiratory distress.

Dermatitis caused by formaldehyde solutions is a well known problem $(34,75)$.

\section{Summary and recommendations}

Formaldehyde can cause DNA damage in bacteria, yeast, and mammalian cells. It is mutagenic in many test systems. Formaldehyde has induced a rare form of cancer in rats and mice, as reported by the Chemical Industry Institute of Toxicology and by the New York University Medical Center. In spite of inadequate epidemiologic findings, evidence of its genotoxicity and carcinogenicity in animals makes it likely that formaldehyde is also a human carcinogen. For this reason formaldehyde should be handled in the workplace as a potential occupational carcinogen. The US National Institute for Occupational Safety and Health has published guidelines for minimizing employee exposure to formaldehyde (67).

\section{Other antimicrobial agents}

Hexachlorophene (2,2'-methylenebis [3,4,6trichlorophenol]) has been used extensively as an antibacterial and antifungal agent.

Hexacholorophene can penetrate both the skin and the placental barrier. A local application of hexachlorophene to the skin can cause neurotoxicity in animals $(73,85)$. Both positive and negative studies have been published on the teratogenicity of hexachlorophene in experimental animals [see Halling (38)].

Metabolites of hexachlorophene can bind covalently to cellular macromolecules (64).

Retrospective epidemiologic studies carried out in six Swedish hospitals have raised concern about congenital malformations in neonates born to women who used hexachlorophene soaps in hospitals (frequent handwashings together with the extensive use of hand creams) (38). Halling's original findings prompted a subsequent study of the outcome of pregnancy in hospital personnel by the National Board of Health and Welfare in Sweden. In this study the perinatal death rates and malformation in the children of hospital personnel were surveyed during 19731975. No significant differences were found, except for an excess of perinatal deaths among the children of hospital personnel in 1973 only (4). A case-referent study of 340 children born with oral clefts in Finland revealed no excess exposure to 
hexachlorophenol among the case mothers (43). Thus the nature and the level of the potential risk linked to the use of hexachlorophene is still unclear.

Sodium o-phenylphenate, a fungicide and antimicrobial agent used, eg, in many hospital soaps, has recently been shown to cause tumors in the urinary tract of rats (44).

Propylene oxide has been found mutagenic in Neurospora. Drosophila, and Salmonella typhimurium bacteria (72). Propylene oxide has also been shown to be a carcinogen $(21,90)$.

\section{DISCUSSION}

Existing knowledge on occupational hazards in hospitals has traditionally been more concerned with such conditions as ionizing radiation or potentially lifethreatening diseases, eg, hepatitis $B$, than with chemical hazards. However, occupational skin diseases are certainly of importance in hospitals, due to the use of chemicals with irritant properties (such as disinfectants and detergents) or due to the allergic dermatoses arising from certain metals, aldehydes, antibiotics, or rubber products. In addition to the use of reactive chemicals in disinfection and cleaning processes, potent biologically active chemicals are being used in cancer chemotherapy. The use of anticancer drugs in cancer chemotherapy is for the benefit of the patients, and, in the same context, care should be taken not to have any unnecessary exposure of the hospital staff, the agents also having mutagenic, teratogenic, and cancer-causing properties.

Women form a large proportion of hospital employees in all countries. Pregnancy outcome studies have been frequently done among operating room personnel in many countries. However, such studies are almost nonexistent among other occupational groups in hospitals. As concluded also by a recent working group of the World Health Organization (92), pregnancy outcome studies of employees in areas such as oncology units or those exposed to chemical sterilants should be encouraged.

Although chemical hazards within hospitals are legion, epidemiologic studies showing risks are infrequent. This lack may be due to the nonexistence of real risks or to the fact that studies simply have not been performed or to the wide use of chemicals having begun only in the late 1960s. The most prominent effects of occupational chemical exposures detected so far have been dermatologic problems and spontaneous abortions among operating room personnel. In addition to the chemical risks dealt with in this review, there are many other potential chemical hazards related to, eg, the use of plastic biomaterials $(19,39,62,74)$. While the well-established infection diseases must not be forgotten, more emphasis should be placed in the future on the possible chemical hazards in hospitals.

\section{REFERENCES}

1. Adamson RH, Sieber SM. Carcinogenic potential of cancer chemotherapeutic agents in man. Cancer bull 29 (1977) 179-183.

2. Amess JAL, Rees GM, Burman JF, Nancekievill DG, Mollin DL. Megaloblastic hemopoiesis in patients receiving nitrous oxide. Lancet 2 (1978) 339.

3. Baden JM, Simmon VF. Mutagenic effects of inhalational anesthetics. Mutat res 75 (1980) 169-189.

4. Baltzar B, Ericson A, Källen B. Pregnancy outcome among women working in Swedish hospitals. N engl j med 300 (1979) $627-628$.

5. Bruce DL, Eide KA, Linde HW, Eckenhoff, JE. Causes of death among anesthesiologists - A 20-year survey. Anesthesiology 29 (1968) $565-569$.

6. Bruce DL, Eide KA, Smith MJ, Seltzer F, Dykes MHM. A prospective survey of anesthesiologists mortality 1967-1971. Anesthesiology 41 (1974) $71-74$.

7. Brøgger A. Caffeine-induced enhancement of chromosome damage in human lymphocytes treated with methylmetanesulphonate, mitomycin $\mathrm{C}$ and $\mathrm{X}$-rays. Mutat res 23 (1974) 353-360.

8. Chang LW, Dudley AW Jr, Lee YK, Katz J. Ultrastructural changes in the nervous system after chronic exposure to halothane. Exp neurol 45 (1974) 209-219.

9. Chang LW, Dudley AW Jr, Lee YK, Katz J. Ultrastructural changes in the kidney following chronic exposure to low levels of halothane. Am j pathol 78 (1975) 225-232.

10. Clayton GD, Clayton FE, ed. Patty's industrial hygiene and toxicology. Third revised edition, volume 2A. John Wiley \& Sons, New York, NY 1978, p 2186.

11. Clements J, Todd NK. Halothane and nondisjunction in Drosophila. Mutat res 91 (1981) 225-228.

12. Cohen EN, Bellville JW, Brown BW. Anesthesia, pregnancy, and miscarriage: A 
study of operating room nurses and anesthetists. Anesthesiology 35 (1971) 343347.

13. Cohen EN, Brown BW, Bruce DL, Cascorbi HF, Corbett TH, Jones TW, Whitcher CH. Occupation disease among operating room personnel: A national study. Anesthesiology 41 (1974) $321-340$.

14. Cohen EN, Brown BW, Bruce DL, Cascorbi HF, Corbett TH, Jones TW, Whitcher CH. A survey of anesthetic health hazards among dentists. J am dent assoc 90 (1975) $1291-1296$.

15. Cohen EN, Brown BW, Wu ML, Whitcher CE, Brodsky JB, Gift HC, Greenfield W, Jones TW, Driscoll EJ. Occupational disease in dentistry and chronic exposure to trace anesthetic gases. J am dent assoc 101 (1980) 21-31.

16. Corbett TH, Ball GL. Chronic exposure to methoxyflurane: A possible occupational hazard to anesthesiologists. Anesthesiology 34 (1971) 532.

17. Corbett TH, Cornell RG, Endres JL, Lieding $\mathrm{K}$. Birth defects among children of nurse-anesthetists. Anesthesiology 41 (1974) $341-344$.

18. Dahlgren B-E. Fluoride concentration in urine of delivery ward personnel following exposures to low concentrations of methoxyflurane. J occup med 21 (1979) $624-626$.

19. Delbressine LPC, Seutter-Berlage F, Seutter E. Identification of urinary mercapturic acids formed from acrylate, methacrylate and crotonate in the rat. Xenobiotica 11 (1981) 241.

20. Doll R, Peto R. Mortality among doctors in different occupations. Br med j 1 (1977) 1433-1436.

21. Dunkelberg $H$. On the oncogenic activity of ethylene oxide and propylene oxide in mice. $\mathrm{Br} \mathrm{j}$ cancer 39 (1979) 588-589.

22. Edling C. Anesthetic gases as an occupational hazard - A review. Scand $j$ work environ health 6 (1980) 85-93.

23. Ehrenberg L, Hällström T. Hematologic studies on persons occupationally exposed to ethylene oxide. In: International Atomic Energy Association. Radiosterilization of medical products. Vienna 1967, pp 327334.

24. Ehrenberg L, Hällström T, OstermanGolkar S. Kriteriedokument för gränsvärden: Etylenoxid. Arbetarskyddverket, Stockholm 1981. (Arbete och hälsa 6).

25. Ericson A, Källen B. Survey of infants born in 1973 or 1975 to Swedish women working in operating rooms during their pregnancies. Anesth analog (Cleveland) 58 (1979) 302-305.

26. European Chemical Industry Ecology \& Toxicology Centre. Assessment of data on the effects of formaldehyde on humans. Brussels 1981. (Technical report no 1).

27. European Chemical Industry Ecology \& Toxicology Centre. The mutagenic and carcinogenic potential of formaldehyde. Brussels 1981. (Technical report no 2).

28. Falck K, Gröhn P, Sorsa M, Vainio H,
Heinonen E, Holsti LR. Mutagenicity in urine of nurses, handling cytostatic drugs. Lancet 1 (1979) 1250-1251.

29. Fiserova-Bergerova V, Holaday DA. Uptake and clearance of inhalation anesthetics in man. Drug metab rev 9 (1979) 4360.

30. Gandolfi AJ, White RD, Sipes G, Pohl LR. Bioactivation and covalent binding of halothane in vitro: Studies with $\left[{ }^{3} \mathrm{H}\right]-$ and [14C]halothane. J pharmacol exp ther 214 (1980) 721-725.

31. Garrett S, Fuerst R. Sex-linked mutations in Drosophila after exposure to various mixtures of gas atmospheres. Environ res 7 (1974) 286-293.

32. Garro AJ, Phillips RA. Mutagenicity of the halogenated olefin, 2-bromo-2-chloro1,1-difluoroethylene, a presumed metabolite of the inhalation anesthetic halothane. Mutat res 54 (1978) 17-22.

33. Garry VF, Hozier J, Jacobs D, Wade RL, Gray DG. Ethylene oxide: Evidence of human chromosomal effects. Environ mutagenesis 1 (1979) 375-382.

34. Glass WI. An outbreak of formaldehyde dermatitis. $\mathrm{Nz}$ med j 60 (1961) 423-427.

35. Göthe C-J, Dahlgren B-E, Hultén B, Olander L, Övrum P, Westerholm P. Narkosgaser som yrkesrisk. Läkartidningen 73 (1976) 2553-2563.

36. Graham CW. Immunological and carcinogenic side effects of anesthetics. Int anesth 18 (1980) 173-186.

37. Guarino AM. Pharmacologic and toxicologic studies of anticancer drugs: Of sharks, mice and men (and dogs and monkeys). In: De Vita VT Jr, Busch $\mathrm{H}$, ed. Methods in cancer research. Volume XVII, part B. Academic Press Inc, New York, NY 1979 , pp 91-174.

38. Halling H. Suspected link between exposure to hexachlorophene and malformed infants. Ann ny acad sci 320 (1979) 426435.

39. Halpern BD, Karo W. Medical applications. In: Bikales NM, ed. Encyclopedia of polymer science and technology, plastics, resins, rubbers, fibers. Supplement, volume 2, Interscience, New York, NY 1977 pp 369, $379-381 \& 385$.

40. Harris CC. The carcinogenicity of anticancer drugs: A hazard in man. Cancer 37 (1976) 1014-1023.

41. Hedström C-E, Olsson B. Undersökning av narkossköterskor jämte matchad kontrollgrupp - en psykologisk och medicinsk studie. Göteborgs Stads Förvaltningshälsovård, Göteborg 1979. (FHV-rapport nr 55).

42. Hendrick DJ, Lane DJ. Occupational formalin asthma. $\mathrm{Br} \mathrm{j}$ ind med 34 (1977) $11-$ 18.

43. Hernberg S, Holmberg P, Rantala K, Kurppa $K$. Relationship between congenital oral clefts and maternal chemical and physical exposures during pregnancy. In: XX International Congress on Occupational Health, Cairo, Egypt, 26. 9.-1. 10. 1981, Abstracts. 1981.

44. Hiraga $\mathrm{K}$, Fujii $\mathrm{T}$. Induction of tumours 
of the urinary system in F344 rats by dietary administration of sodium o-phenylphenate. Food cosmet toxicol 19 (1981) 303310.

45. Högstedt B, Hedner K, Kolnig A-M, Mitelman F, Skerfving S, Gullberg B. Chromosomal damage in bone marrow cells and peripheral blood lymphocytes in humans exposed to ethylene oxide. Mutat res (in press).

46. Hogstedt C, Rohlen O, Berndtsson BS, Axelson O, Ehrenberg L. A cohort study of mortality and cancer incidence in ethylene oxide production workers. $\mathrm{Br} \mathrm{j}$ ind med 36 (1979) 276-280.

47. Hogstedt $\mathrm{C}$, Malmqvist $\mathrm{N}$, Wadman $\mathrm{B}$. Leukemia in workers exposed to ethylene oxide. J am med assoc 241 (1979) 11321133.

48. Honeycombe JR. The effects of busulphan on the chromosomes of normal human lymphocytes. Mutat res 57 (1978) 35-49.

49. Jensen OM. Cancer risk from formaldehyde. Lancet 2 (1980) $480-481$.

50. Knill-Jones RP, Newman BJ, Spence AA. Anaesthetic practice and pregnancy: Controlled survey of male anaesthetists in the United Kingdom. Lancet 2 (1975) 807-809.

51. Knill-Jones RP, Rodrigues LV, Moir DD, Spence, AA. Anaesthetic practice and pregnancy: Controlled survey of women anaesthetists in the United Kingdom. Lancet 1 (1972) 1326-1328.

52. Korttila K, Pfäffli P, Linnoila M, Blomgren $E$, Hänninen $\mathrm{H}$, Häkkinen $\mathrm{S}$. Operating room nurses' psychomotor and driving skills after occupational exposure to halothane and nitrous oxide. Acta anaesthesiol scand 22 (1978) 33-39.

53. Kramers PGN, Burm AGL. Mutagenicity studies with halothane in Drosophila melanogaster. Anesthesiology 50 (1979) $510-513$.

54. LaBorde JB, Kimmel CA. The teratogenicity of ethylene oxide administered intravenously to mice. Toxicol appl pharmacol 56 (1980) 16-22.

55. Lambert B, Lindblad A, Holmberg $\mathrm{K}$, Francesconi D. The use of sister chromatid exchange to monitor human populations for exposure to toxicologically harmful agents. In: Wolff S, ed. Sister chromatid exhange. John Wiley \& Sons, Inc, New York, NY 1982, pp 149-182.

56. Lane GA, Nahrwold ML, Tait AR, Taylor BS, Beaudoin AR, Cohen PJ. Nitrous oxide is teratogenic: Xenon is not! Anesthesiology 51 (1979) 260.

57. Layzer RB. Myeloneuropathy after prolonged exposure to nitrous oxide. Lancet 2 (1978) $1227-1230$.

58. Layzer RB, Fishman RA, Schafer JA. Neuropathy following abuse of nitrous oxide. Neurology 28 (1978) 504-506.

59. Littlefield LG, Colyer SP, Sayer AM, DuFrain RJ. Sister chromatid exchanges in human lymphocytes exposed during $G_{0}$ to four classes of DNA-damaging chemicals. Mutat res 67 (1979) 259-269.

60. Matanoski GM. Speech given at the In- teragency Collaborative Group on Environmental Carcinogenesis meeting of the National Cancer Institute on 6 February 1980 at the John Hopkins University in Baltimore, MD. Cited by European Chemical Industry Ecology \& Toxicology Centre. Assessment of data on the effects of formaldehyde on humans. Brussels 1981. (Technical report no 1 ).

61. Mazze RJ, Calverley RK, Smith T. Inorganic fluoride nephrotoxicity: Prolonged enflurance and halothane anesthesia in volunteers. Anesthesiology 46 (1977) 265271.

62. McLaughlin RE, Regar SI, Barkalow JA Allen MS, Difacio CA. Methylmethacrylate: A study of teratogenicity and fetal toxicity of the vapor in the mouse. $J$ bone jt surg 60 (1978) 355 .

63. Ménard DB, Gisselbrecht C, Marty M, Reyes F, Dhumeaux D. Antineoplastic agents and the liver. Gastroenterology 78 (1980) 142-164.

64. Miller III A, Henderson MC, Buhler DR. Cytochrome P-450-mediated covalent binding of hexachlorophene to rat tissue proteins. Mol pharmacol 14 (1978) 323-336.

65. National Institute for Occupational Safety and Health. Occupational exposure to waste anesthetic gases and vapors. US Department Health, Education and Welfare, Washington, DC 1977.

66. National Institute for Occupational Safety and Health. Use of ethylene oxide as a sterilant in medical facilities: Special occupational hazard review, Rockville, MD 1977.

67. National Institute for Occupational Safety and Health. Ethylene oxide. Curr intell bull 35 (1981) $1-22$.

68. National Institute for Occupational Safety and Health. Formaldehyde - Evidence of carcinogenicity. Curr intell bull 34 (1981) $1-15$.

69. National Research Council. Formaldehyde - An assessment of its health effects. Prepared for the Consumer Product Safety Commission, National Academy of Sciences, Washington, DC 1980, pp 1-38.

70. Norppa $H$, Sorsa $M$, Vainio H, Gröhn $P$, Heinonen E, Holsti L, Nordman E. Increased sister chromatid exchange frequencies in lymphocytes of nurses handling cytostatic drugs. Scand $j$ work environ health 6 (1980) 299-301.

71. Penn I. Chemical immunosuppression and malignancy. Cancer 34 (1974) 1474 - 1480.

72. Pfeiffer EH, Dunkelberg H. Mutagenicity of ethylene oxide and propylene oxide and of the glycols and halohydrins formed from them during fumigation of foodstuffs. Food cosmet toxicol 18 (1980) 115-118.

73. Pleasure D, Towfight J, Silberberg D, Parris J. The pathogenesis of hexachlorophene neuropathy, in vivo and in vitro studies. Neurology 24 (1974) 1068-1075.

74. Poss R, Thilly WG, Kaden DA. Methylmethacrylate is a mutagen for Salmonella typhimurium. J bone jt surg 61 (1979) 1203-1207. 
75. Proctor NH, Hughes JP. Chemical hazards of the workplace. JB Lippincott, Philadelphia, PA 1978, pp 272-274.

76. Quimby KL, Aschenase LJ, Bowman RE, Katz I, Chang LW. Enduring learning deficits and cerebral synaptic malformation from exposure to 10 parts of halothane per million. Science 185 (1974) 625-627.

77. Rosenberg P, Kirves A. Miscarriages among operating theater staff. Acta anaesthesiol scand 53 (1973) 37--42.

78. Schmäl D. Carcinogenic action of anticancer drugs with special reference to immunosuppression. Cancer 40 (1977) 19271929.

79. Sharp JH, Trudell JR, Cohen EN. Volatile metabolites and decomposition products of halothane in man. Anesthesiology 50 (1979) $2-8$.

80. Sieber SIM, Adamson RH. Toxicity of antineoplastic agents in man: Chromosomal aberrations, antifertility effects, congenital malformations and carcinogenic potential. Adv cancer res 22 (1975) 57-155.

81. Snellings WM, Weil CS, Maronpot RR. Final report on ethylene oxide two-year inhalation study on rats: Project report 44-20, Bushy Run Research Center (formerly Carnegie-Mellon Institute of Research), January 28, 1981. Submitted by Union Carbide Corporation to the US Environmental Protection Agency under Section $8(\mathrm{e})$ of the Toxic Substances Control Act, on behalf of cosponsors of the study (February 1981).

82. Spence AA, Knill-Jones RP. Is there a health hazard in anaesthetic practice? $\mathrm{Br} \mathrm{j}$ anaesth 50 (1978) 713-719.

83. Stevens WC, Eger EI II, White A, Halsey MJ, Munger W, Gibbons RD, Dolan W, Shargol R. Comparative toxicities of halothane, isoflurane and diethyl ether at subanesthetic concentrations in laboratory animals. Anesthesiology 42 (1975) 408-419.

84. Tolonen M. Occupational hazards of the health professions. Working paper presented in the Meeting on Occupational Hazards in Hospitals, The Hague, 19-21 October, 1981, pp 1-27.

85. Udall V. Drug-induced blindness in some experimental animals and its relevance to toxicology. Proc r soc med 65 (1972) 197200.

86. Upton A. A letter to governmental officers. August 17, 1981.

87. Vaisman AI. Working conditions in surgery and their effect on the health of anesthesiologists. Eksp khir anesteziol 12 (1967) 4449.

88. Vaughan RW, Sipes IG, Brown BR. Role of biotransformation in the toxicity of inhalation anesthetics. Life sci 23 (1978) $2447-2462$.

89. Waksvik H, Klepp O, Brogger A. Chromosome analyses of nurses handling cytostatic drugs. Cancer treat rep 65 (1981) $607-$ 610.

90. Walpole AL. Carcinogenic action of alkylating agents. Ann ny acad sci 68 (1958) 750 .

91. Weisburger JH, Griswold DP, Prejean JD, Casey AE, Wood HB, Weisburger EK. In: Grundmann E, Gross R, ed. Recent results in cancer research. Springer-Verlag, Berlin and New York, NY 1975, pp 1-17.

92. Working Group on Occupational Hazards in Hospitals. Summary report. The Hague 20-22 October 1981. World Health Organization, Regional Office for Europe, Copenhagen 1981, pp $1-4$

Received for publication: 15 March 1982 